\title{
Conflict Resolution Model Development of Oil Palm Plantation Land-Based on Local Wisdom Values in North Mamuju Regency
}

\author{
Nuryanti Mustari ${ }^{1}$, Ihyani Malik ${ }^{1}$, Nasrulhaq $^{1}$, Zulfan Nahruddin $^{1}$ \\ \{nuryantimustari@unismuh.ac.id ${ }^{1}$ \} \\ Universitas Muhammadiyah Makassar
}

\begin{abstract}
This study aims to analyze the social problems that cause conflicts disputed oil palm plantations and develop a conflict resolution model based on local wisdom in resolving disputed oil palm plantations. This study designed using qualitative research approaches and another research types that relevant as triangulation to get the source information about the oil palm plantation land conflict resolution based on local wisdom 'massetto ada' 'tau' massetto nyama, manjulu sara manjulu rio, massetto pattaro di Lante samballa, setto kalingulu nisolai, A qualitative approach used to analyze in depth how the conflict resolution model of local knowledge-based society. Results showed that the management of social problems, political and agrarian caused the prolonged vertical conflict occurs even escalation of conflicts that the government and other parties cannot solve it. Alternative solutions through dialogue can serve as a reference for the government to tackle the conflict. The government though has its own ways and methods to resolve conflicts although repressive and militaristic through the top-down approach of institutional/structural. However, the bottom-up approach is an alternative in solving conflicts, another approach and conflict resolution method can elaborate that.
\end{abstract}

Keywords: Land conflicts, Plantation, Value, Local Wisdom

\section{Introduction}

Conflict governance is a series of coordinated structured actions for all elements in conflict in a conflict [1]. Conflict governance leads to a process-oriented approach that refers to the form of communication-related to the behavior of various elements involved in the way of communicating and influential culture [2], [3]. In the colonial era, land conflicts occurred because of differences in interests between the colonizers and the colonized (indigenous), thus impacting the legal conflict, namely with the enactment of the land law dualism [4],[5]. In the era of independence and current reform, land conflicts arise because of conflicts of individual interests and conflicts of interests between groups [6]. In addition, because of the conflict between public interests and the interests of individuals and community groups [7]. A real example of vertical conflict between the oil palm farming community and the palm oil plantation company in North Mamuju.

North Mamuju is well-known as the main producer of palm oil in West Sulawesi, but apparently in North Mamuju there are still many unemployed people and the poor due to the 
lack of equal distribution of economic growth from the contribution of oil palm companies. The existence of oil palm companies does not accommodate the interests of the local population and is less contributing to increase the Regional Original Revenue (PAD). Palm oil CPO production in North Mamuju is 500,000 tons per year with a level of contribution provided through third party donations of IDR 800,000,000 per year. Contributions are very small compared to the amount of income earned or the area of land that is controlled by the company. These conditions cause conflict, because there is no significant effect on the people who manage the land.

The tensions that occur are involving the village community with the company. Responding to this problem, it is necessary to have reliable strategies in the form of maintaining integration in people's lives in the hope that vertical conflicts that occur do not seep on horizontal conflict, so that it will damage the social order that has been flourishing for a long time. Not only a land issue, there are still many social problems faced by communities that have the potential to conflict, so that a proper model is needed in its resolution.

Research on conflict resolution with a social cultural approach Winslade and Monk [8] and conflict resolution with the militant approach Nuciari [9] has different completion characteristics and different impacts. This research is indispensable for designing development new model in the effort to resolve land disputes based on local wisdom "massetto there is 'tau' massetto nyama, manjulu sara manjulu rio, massetto pattaro in lante samballa, setto kalingulu nisolai in North Mamuju Regency, where the conflict resolution applied is curative not in preventive efforts, with the step of developing a conflict resolution model, it is hoped that the government, especially the district / city level government, can find an initial strategy in maintaining national integrity in the midst of ethnic, cultural and religious diversity.

\section{Method}

This research was conducted on 3 locations of conflict palm oil fields in North Mamuju District, namely Barubu Hamlet, Bukit Harapan Village, Bulutaba District, and Towoni Village, Baras District, as well as the community in Lariang District. The private sector is also part of the object of this research namely PT. Astra Agro Lestari Tbk, the Land Office and several Indigenous Peoples and Religious Forum forums such as the FKUI, the Inter-Church Harmony Forum, the Darma Hindu and Pastoral Council Forum which are directly related to the activities of resolving conflicts over oil palm plantations. The location of this study was centered in North Mamuju Regency because the institutions and institutions or objects of research were also in the North Mamuju region. The design of this study uses qualitative research approaches and other types of relevant research such as triangulation to obtain information sources on the resolution of conflicts over oil palm plantations based on massetto local wisdom there is 'tau' massetto nyama, manjulu sara manjulu rio, massetto pattaro in lante samballa, setto kalingulu nisolai. There are three steps of qualitative data processing in this study namely data reduction, data display, and conclusion drawing and verification. 


\section{Result and Discussion}

\subsection{Causes of Conflict in the Land Dispute for Oil Palm Plantation}

Conflict of land disputes that occurred in North Mamuju Regency was a long-standing conflict, caused by several things such as the presence of seeds of potential conflict between the local community and the company PT. Mamuang in North Mamuju Regency. The cause of the conflict escalation was caused by each party claiming ownership of oil palm plantation land. The community claimed that the company had taken community-owned plantation land in the sense of an expansion of the oil palm company's land area. Expansion of private plantation land.

Based on interviews, it was found that there was an increase in the area of oil palm plantations in North Mamuju District in 2005-2010, that in 2005 the plantation area was 41.2 thousand hectares, and an increase in 2007 was 52.2 thousand hectares, in 200852.2 thousand $\mathrm{Ha}$, and in 200952.2 thousand $\mathrm{Ha}$, although in 2010 there was a significant decline in the land area of 30.7 thousand $\mathrm{Ha}$, because there had been a conflict between the community and the company. Other social problems that cause vertical conflict [10].

This research shows that between the community and the company, it is found that the economy becomes a conflict, namely the lack of local Mamuju North PAD revenue in the palm oil plantation sector. Palm oil in this area has not fully contributed to income in the context of development in North Mamuju Regency. Conflict resolution efforts are needed that pay attention to the economic aspects of the components involved in the conflict [11], [12].

Factors of low local original income in North Mamuju Regency, especially in the oil palm plantation sector, Mamuju District communities, especially in Pasangkayu Subdistrict, are still classified as weak economic communities that lack income in the oil palm plantation sector which encourages conflict. Based on the results of interviews with members of the Regional People's Legislative Assembly (DPRD), the management of oil palm plantations in North Mamuju District faces social, political and literary problems which is the cause of prolonged vertical conflicts and even escalation of conflicts that cannot be resolved by the government or other parties. Therefore, the central government and regional governments, the private sector (oil palm companies) and local communities and indigenous peoples must be able to find methods to resolve the land dispute conflict. On the other hand, the conflict that occurred was not in line with the vision of the North Mamuju district government that would make North Mamuju Regency an agropolitan district.

\subsection{Development of a conflict resolution model based on local wisdom}

In managing land dispute conflicts between the community and PT Mamuang, and several other private companies have not found a win-win solution, the potential for post-conflict conflict is still very much felt in North Mamuju District. Both parties are not able to be mediated by the local government, both the North Mamuju District government and the West Sulawesi Provincial Government because of the lack of public trust in the existing regional government, the community considers that the provincial and district governments are less than optimal for resolving land dispute conflicts, even the community feels that the provincial and district governments are aligning with the private sector.

The results of interviews with traditional leaders responded in line with the facts that occurred in North Mamuju District that since 2010-2016 conflicts over land disputes over oil palm plantations between the community and the private sector have not been able to find a 
solution. The government is only able to act coercively (coercive) through a militaristic approach that is owned to reduce conflict that occurs so that the conflict is dim but there can be potential for post-conflict conflict. The local government does not resolve the conflict to the root of the problem, the demands of the community and the demands of the private sector have not been able to be accommodated in a number of arrangements at the local level.

However, the conflict became cold after initiatives carried out by traditional leaders in North Mamuju District who were willing to act as negotiators and mediators in resolving conflicts between the community and the private sector and even the government. The initiative was carried out in order to observe the various conflicts over oil palm plantations that occurred every year that were not completed, the resolution of the land dispute conflict sought to be resolved by carrying out cultural approaches as part of local wisdom in North Mamuju District.

Based on the results of interviews with representatives of adat institutions, it was concluded that in addition to the government's structural approach through repressive methods that cannot resolve the land dispute conflicts that occur, indigenous peoples have alternative solutions to problem-solving and conflict resolution using cultural approaches or in other words grassroots approaches to community and through character involvement - customary leaders, youth organizations and other social organizations. Local wisdom that is owned by the people in North Mamuju Regency, the slogan binds the people in the area, moreover the parents of the local villages and villages still really appreciate the traditions and culture of the area. The customs framed in the slogan are cultural wealth in the community of North Mamuju Regency which can be used as reconciliation efforts, and resolving conflicts as well as an alternative for conducting conflict resolution. The conflict that has escalated which makes the atmosphere tense requires demands from many parties to immediately hold a dialogue, which is generally understood as an exchange and discussion of ideas, which is honestly conveyed to be important dialogue [13], [14].

The dialogical process between the community of oil palm farmers and the private sector is carried out by community leaders, traditional leaders and local government by trying to mediate and reconcile related to the main contrain of the conflict. So, the birth of the buttomup conflict resolution through cultural approaches and local wisdom possessed, namely the massetto there is 'tau' massetto nyama, manjulu sara manjulu rio, massetto pattaro in lante samballa, setto kalingulu nisolai, which means that Bersatu upholds adat, unites in heart, sorrow and taste, cheerful feeling, united determination on a mat, one pillow two heads. The wealth of customs and culture of the local community can be an alternative for resolving vertical conflicts that occur between oil palm farming communities and the private sector, although initially only able to reduce the potential for post-conflict conflict, but if local wisdom is preserved and maintained by all parties then peace will be more easily achieved, the process of peace making and peace building will be well implemented.

Alternative solutions can also be a reference for the government in making efforts to resolve prolonged conflicts. The government even though has its own methods and methods in resolving conflicts even though it is very repressive and militaristic through an institutional top-down approach [15]. The buttom-up approach is the best alternative in resolving conflicts that can be elaborated by conflict resolution approaches and methods that Another development of this model can be adopted in local government policies in dealing with conflicts that occur, policy implementation can be accompanied by dialogue involving all elements [16], aspects of organizational culture in the government apparatus can help conducive the situation [17]. Aspects of partnership between the government and the community can minimize conflicts that can occur [18]. Management of oil palm plantations in 
North Mamuju District must be regulated through active government roles by issuing policies public who are pro to the Regency community North Mamuju. In essence, the conflict resolution approach through a butt-up approach must always be maintained and preserved in order to find a formulation of conflict resolution that is in accordance with the culture of North Mamuju District society.

\section{Conclusion}

The results of this study indicate that there is an escalation of conflict that is not able to be resolved by both the government and other parties. the conflict that occurred was not in line with the vision of the North Mamuju district government. The dialogical process between the community of oil palm farmers and the private sector is carried out by community leaders, traditional leaders and local government by trying to mediate or play contrain) the occurrence of the conflict. Thus, the birth of the buttom-up conflict resolution through cultural approaches and local wisdom possessed namely manifesting united values upholding customs, united in the heart, sorrow and taste, cheerful feel, united determination on a mat, one pillow two heads. The wealth of customs and culture of the local community can be an alternative for resolving vertical conflicts that occur between the oil palm farming community and the private sector. Local wisdom that is preserved results in a process of peace making and peace building that can be held well.

\section{References}

[1] M. M. Montoya-Weiss, A. P. Massey, and M. Song, "Getting it together: Temporal coordination and conflict management in global virtual teams," Acad. Manag. J., vol. 44, no. 6, pp. 62-1251, 2001.

[2] S. Ting-Toomey and A. Kurogi, "Facework competence in intercultural conflict: An updated face-negotiation theory"," Int. J. Intercult. relations, vol. 22, no. 2, pp. $187-$ 225, 1998.

[3] D. G. Ellis and I. A. Maoz, "Communication And Cultural Codes Approach To Ethnonational Conflict,” Int. J. Confl. Manag. 14, vol. 3, no. 4, pp. 255-720, 2003.

[4] C. C. Thorburn, "The plot thickens: land administration and policy in post-new order Indonesia," Asia Pacific Viewpoint”, vol. 45, no. 1, pp. 33-49, 2004.

[5] H. Alting, "Penguasaan Tanah Masyarakat Hukum Adat Suatu Kajian Terhadap Masyarakat Hukum Adat Ternate," J. Din. Huk., vol. 11, no. 1, pp. 87-98, 2011.

[6] F. Ismail, "Keteladanan dalam konteks kepemimpinan nasional dan realitas kemajemukan bangsa," UNISIA, vol. 52, pp. 105-108, 2016.

[7] P. J. Culhane, "Public lands politics: Interest group influence on the Forest Service and the Bureau of Land Management." RFF Press, 2013.

[8] J. Winslade and G. Monk, A new approach to conflict resolution. San Francisco: Jossey-Bass, 2001.

[9] M. Nuciari, Handbook of the Sociology of the Military. New York: Springer. ., 2006.

[10] M. Granovetter, "Economic action and social structure: The problem of embeddedness," Am. J. Sociol., vol. 91, no. 3, pp. 481-510, 1985.

[11] D. Rucht, "The transnationalization of social movements: Trends, causes, problems," in Social movements in a globalizing worl, London: Palgrave Macmillan, 1999, pp. 206-222.

[12] J. F. Gaski, "The theory of power and conflict in channels of distribution," J. Mark., 
vol. 9, no. 29, 1984.

[13] J. Forester, "Making participation work when interests conflict: Moving from facilitating dialogue and moderating debate to mediating negotiations," J. Am. Plan. Assoc., vol. 72, no. 4, pp. 447-456, 2006.

[14] D. Tjosvold, "The conflict-positive organization: It depends upon us," J. Organ. Behav. Int. J. Ind. Occup. Organ. Psychol. Behav., vol. 29, no. 1, pp. 19-28, 2008.

[15] R. Youngs, "Democratic institution-building and conflict resolution: emerging EU approaches," Int. Peacekeeping, vol. 11, no. 3, pp. 526-543, 2004.

[16] N. Mustari, Implementasi Kebijakan Publik (Pemahaman Teoritis Empiris). Makassar: Membumi Publishing, 2013.

[17] Z. Nahruddin and H. Tambajong, "The Behavior of Apparatus and Cultural Organization in Provision of Public Service in District Level," Sch. J. Arts, Humanit. Soc. Sci., vol. 5, no. 7b, pp. 716-720, 2017.

[18] R. Raman, I. Malik, and H. Hamrun, "Kemitraan Pemerintah Daerah Dengan Kelompok Masyarakat Dalam Pengelolaan Hutan Mangrove di Desa Tongke-Tongke Kabupaten Sinjai,” Otoritas J. Ilmu Pemerintah., vol. 5, no. 2, pp. 189-201, 2015. 